\title{
Impact Assessment of Front Line Demonstrations on Musard (Brassica juncea) in Bhiwani District of Haryana, India
}

\author{
Vinod Kumar and D. S. Jakhar* \\ Krishi Vigyan Kendra, Mandkola, KVK Sirsa, India \\ *Corresponding author
}

\begin{abstract}
A B S T R A C T
\section{Keywords}

Irrigated, Low in nitrogen, Medium in phosphorus and potash and the soil

Article Info

Accepted:

04 March 2020

Available Online:

10 April 2020

Krishi Vigyan Kendra, Bhiwani had conducted Front Line Demonstration (FLD) at the farmers' field in the villages of districts Bhiwani \& Dadri during 2015-16, 2016-17 and 2017-18. The critical inputs were identified in existing production technology through meetings \& discussions with farmers. The farming situation of demonstration fields was irrigated, low in nitrogen, medium in phosphorus and potash and the soil was sandy loam. The crop rotation was pearl millet-mustard, cluster bean-mustard and mung bean-mustard. Delayed sowing, use of improper dose of seed and fertiliser, uncontrolled weeds $\&$ lack of plant protection measures were predominant identified cause of low productivity of mustard crop in district Bhiwani. In the same sequence the other parameters like technological impact, economical impact \& extension gap were analyzed for impact assessment of front line demonstration on mustard crop \& feasibility of demonstrated technologies at grass root levels. The results of three years revealed that During the $1^{\text {st }}$ year $(2015-16)$ the variety perform very well with an average yields of 22.20 which was $30.60 \%$ higher than the check variety $(17.00 \mathrm{q} / \mathrm{ha})$. On the basis of $1^{\text {st }}$ year result the demonstration was continued next year i.e during 2016-17 and 2017-18. The three year average data reveals that the grain yield of RH 0749 variety increased by $5.20 \mathrm{q} / \mathrm{ha}(2015-16), 7.40 \mathrm{q} / \mathrm{ha}(2016-17)$ and $7.00 \mathrm{q} / \mathrm{ha}(2017-18)$ over the yield obtained under farmers' practice. The results of FLD's on mustard variety revealed that increase in yield was ranged between $30.60 \%(2015-16)$ and $47.40 \%$ (2016-17) and got between Rs. 6828 and Rs. 11205 additional returns (Table-4) from demonstrations field over farmers' practice. This increase was with an extra expenditure of approximately Rs. 1000 per ha which is very less and even small and marginal farmers could also afford. An extension gap ranging from 520-740 kg per hectare was found between front line demonstrations and farmers practices during the different time line.
\end{abstract}

\section{Introduction}

The Front Line Demonstration (FLD) is an applied approach to accelerate the dissemination of proven technologies at farmers' fields in a participatory mode with an objective to explore the maximum available resources of crop production and also to bridge the productivity gaps by enhancing the production in national basket. Rapeseed-mustard comprising eight different species viz. Indian mustard, toria, yellow sarson, brown sarson, gobhi sarson, karan rai, black mustard and taramira, are being cultivated in 53 countries spreading all over the globe . Indian mustard (Brassica juncea) is one of the major edible oilseed crops after soyabean and accounts for about 75-80\% of 
the $6.8 \mathrm{~m}$ ha rapeseed mustard crops. In 1986 the government of India started Oilseed Technology Mission for Research and Development of oilseed crops and the productivity increased from $1262 \mathrm{~kg} / \mathrm{ha}$ (2012-13) to $1304 \mathrm{~kg} / \mathrm{ha}$ in the year 2016-17 at national level (Graph 2). The estimated area, production and yield of rapeseedmustard in the world was 36.68 million hectares (mha), 72.42 million tonnes (mt) and $1974 \mathrm{~kg} / \mathrm{ha}$, respectively, during 2017-18 (Graph1). During the last seven years, there has been a considerable increase in productivity from $1840 \mathrm{~kg} / \mathrm{ha}$ in $2010-11$ to $1974 \mathrm{~kg} / \mathrm{ha}$ in 2017-18 and production has also increased from $61.64 \mathrm{~m} \mathrm{t}$ in $2010-11$ to $72.42 \mathrm{~m} \mathrm{t}$ in 2017-18 (Graph1).

Rapeseed \& mustard is occupying 6.07 ha area, 7.92 million tones production and 1304 $\mathrm{kg} / \mathrm{ha}$ productivity in 2016-17.

In spite of this the average production of Rapeseed \& mustard in India is $1.30 \mathrm{t} / \mathrm{ha}$. Which is very lesser than the world average $(1.97 \mathrm{t} / \mathrm{ha})$ (Graph 2). The productivity is quite low due to lack of use of high yielding varieties, sub-optimal application of fertilizers, less use seed treatment, no weed management, and cultivation on marginal lands under rainfed conditions. In other side during January there is a prolonged cool temperature and high relative humidity also affected the growth and development of crop. To demonstrate the need specific technologies such as better varieties, cultural practices of mustard Front Line Demonstrations (FLD's) are laid out at farmer's field by different Krishi Vigyan Kendra's. During the year 2013 Chaudhary Charan Singh Haryana Agricultural University, Hisar released a new high yielding variety RH 0749 at National level having the potential yield $32 \mathrm{q} / \mathrm{ha}$ and recommended for NWPZ under irrigated conditions. Keeping the importance of FLDs, the KVK Bhiwani planned FLD's on Mustard variety "RH 0749" with use of recommended package of practices at farmers' field under irrigated conditions during Rabi 2015-16, 2016-17, \& 2017-18 with following specific objectives includes to assess the impact assessment of recommended package and practices of Mustard compared with farmers practices; and to analyze the economics of recommended package and practices of Mustard.

\section{Materials and Methods}

Krishi Vigyan Kendra (KVK), Bhiwani conducted Front Line Demonstrations (FLDs) at the farmers' field in the villages of Bhiwani \& Dadri districts of Haryana state in India during 2015-16, 2016-17and 2017-18. Farmers were selected randomly from the villages in each year and the area under each demonstration was 0.40 ha. The farming situation of demonstration fields was irrigated, low in nitrogen, medium in phosphorus and high in potash and the soil was sandy loam. The crop rotation was pearl millet-mustard, Pearl millet-mustard \& Cluster bean-mustard. The study was conducted to observe the performance of variety $\mathrm{RH} 0749$ against the existing old variety RH 30. The crop was grown with recommended package and practices. The critical inputs like seed was given free of cost to farmers and seed treatment with bavistin (Fungicide) and bio fertilizers \& Orobanche (Weed) chemical management was applied in demonstration fields. The demonstrations on farmers' fields were regularly monitored from sowing till harvesting by scientists of Krishi Vigyan Kendra, Bhiwani.

Field days and group meetings were also organized to provide the opportunities for other farmers to witness the benefits of demonstrated technologies. The data output were collected from both FLD plots as well as control plots and cost of cultivation, net 
income, and benefit cost ratio were also worked out (Samui et al., 2000). The analytical tool used for assessing the performance of the FLD is as follows:

Extension gap $=$ Demonstration yield Farmers' practice yield

Technology gap $=$ Potential yield Demonstration yield

Technology index $=$ (Potential yield Demonstration yield)x100/Potential yield

\section{Results and Discussion}

The improved variety was used for demonstrations as it has some special characters as given below:

Low incidence of white rust, Sclerotinia stem rot, downy mildew and powdery mildew.

Crop duration is 145-148 days.

Tolerant to lodging and shattering

High oil content up to $39-40 \%$

High average yield i.e. 25-28.75 q/ha.

\section{Grain yield}

The results of all FLD plots over different periods are given in Table 3 . The variety $\mathrm{RH}$ 0749 performs better and provided good yield in comparison with to check in different years. The grain yield of mustard increased by 5.20 q/ha (2015-16), 7.40 q/ha (2016-17) and $7.0 \mathrm{q} / \mathrm{ha}(2017-18)$ over the yield obtained under farmers' practice (Table 3 ). The result is in conformity with the finding of Chaudhary et al., (2018) and Tiwari et al., (2003). These results clearly indicates that due to knowledge and adoption of appropriate technology i.e. RH 0749, seed treatment with fungicide and biofertilizers, use of balanced dose of fertilizer, proper weed management etc. the yield of mustard could be increased between 30.60 and 47.40 per cent over the yield obtained under farmers' practice. The result is in conformity with the finding of
Tiwari and Saxena (2001) and Tiwari et al., (2003).

\section{Economic analysis}

Economic returns was observed to be a function of grain yield and Minimum Support Price (MSP) or sale price which varied along year. Different variables like seed, fertilizers, herbicides and pesticides were considered as cash inputs for the FLD demonstrations as well as for farmers practice. The additional return of demonstrated plots under RH 0749 was Ranged between Rs.6828 and 10205 per ha during different years in comparison with farmers practices. The highest net return (Rs. 29130) was observed during the year 2015-16 than the other years.

This might be due to difference in sale price of produce. The benefit cost ratio was observed higher under HYV variety than the farmers' practice during all the years (Table 4). The results are in More and less similar results were also reported by Hiremath et al., (2007) Dhaka et al., (2010) and Patel et al., (2013). The front line demonstration on mustard variety revealed that increase in yield was ranged between $30.60 \%(2015-16)$ and $47.40 \%$ (2016-17) (Table 3) and got Rs. 10205 and Rs. 6825 additional return (Table 4) over local check.

The superiority of recommended package of practices under frontline demonstration over farmers' practice was also reported by Mitra and Samajdar (2010) and Balai et al., (2012). This increase was with an extra expenditure of approximately Rs.1000 per ha which is very less and even small and marginal farmers could also afford. The kisan gosthies, trainings, field days and regular monitoring the fields by scientists was effective in changing attitude, skill and knowledge of farmers towards improved/recommended practices of wheat cultivation. 


\section{Gap analysis}

The finding of the study revealed that wide gap existed in potential and demonstration yield in high yield Mustard varieties due to technology and extension gap. By conducting frontline demonstration was an effective tool for increasing the productivity of Mustard crop. Improved technologies in frontline demonstrations enhanced yield and increase percent over the farmers practice in local check plots. This will substantially increase the income as well as the livelihood of the farming community. An extension gap ranging from $520-740 \mathrm{~kg}$ per hectare was found between FLD demonstration and farmers practices during the different time line. The extension gap was higher under HYV RH 0749 in the year 2016-17 than rest two years 2015-16 and 2017-18 (Table 5). Such gap might be attributed to adoption of improved technologies in demonstrations which resulted in higher grain yield than that in the farmers' practices. Wide technology gap were observed during these years and this was lowest (9.00) during 2016-17 and was highest (10.1) during 2017-18 (Table 1 and $5)$.

The difference in gap during different years could be due to differential climatic conditions during different years. Similarly, the technology index for all the demonstrations during different years were in accordance with technology gap. Higher technology index reflected the inadequacy of technology and or insufficient extension services for transfer of technology. The results are conformity with the findings of Singh and Kumar (2012). The varietal development of mustard along with their year of release and productivity are given in table 2 .

Table.1 Year wise crop detail demonstrated fields

\begin{tabular}{|l|l|l|l|c|}
\hline Year & Sowing date & Harvesting Date & $\begin{array}{l}\text { Seasonal } \\
\text { Rainfall }\end{array}$ & $\begin{array}{c}\text { No. of } \\
\text { Rainy days }\end{array}$ \\
\hline $\mathbf{2 0 1 5 - 1 6}$ & $10.10 .2015-17.10 .2016$ & $03.03 .2010-19.03 .2010$ & $16.7 \mathrm{~mm}$ & 2 \\
\hline $\mathbf{2 0 1 6 - 1 7}$ & $07.10 .2016-16.10 .2017$ & $1.03 .2011-15.03 .2011$ & $29.9 \mathrm{~mm}$ & 3 \\
\hline $\mathbf{2 0 1 7 - 1 8}$ & $28.09 .2017-19.10 .2018$ & $1.03 .2012-20.03 .2012$ & $19.3 \mathrm{~mm}$ & 4 \\
\hline
\end{tabular}

Table.2 Productivity of different varieties of mustard recommended for Haryana

\begin{tabular}{|l|l|c|l|}
\hline $\begin{array}{l}\text { Sr. } \\
\text { No. }\end{array}$ & Name of Variety & $\begin{array}{l}\text { Year of } \\
\text { release }\end{array}$ & Average Production (q/ha) \\
\hline $\mathbf{1}$ & RH 30 & 1983 & $20-22.5$ \\
\hline $\mathbf{2}$ & Laxmi & 1996 & $22.5-25$ \\
\hline $\mathbf{3}$ & Swarn jyoti & 2002 & $17.50-20.0$ (Suitable for late sown) \\
\hline $\mathbf{4}$ & RB 50 & 2009 & 18.0 (Suitable for rainfed) \\
\hline $\mathbf{5}$ & RH 0749 & 2013 & $25-28.75$ \\
\hline
\end{tabular}


Table.3 Yield analysis of front line demonstrations of mustard on farmers' field

\begin{tabular}{|c|c|c|c|c|c|}
\hline Year & $\begin{array}{l}\text { No. of } \\
\text { demonst } \\
\text { rations }\end{array}$ & $\begin{array}{l}\text { Technology } \\
\text { demonstrated }\end{array}$ & $\begin{array}{l}\text { Demonstration } \\
\text { yield }(q / h a)\end{array}$ & $\begin{array}{l}\text { Farmers Practice } \\
\text { yield }(\mathbf{q} / \mathbf{h a})\end{array}$ & $\begin{array}{l}\text { Percent } \\
\text { increase }\end{array}$ \\
\hline 2015-16 & 50 & $\begin{array}{l}\text { High Yielding } \\
\text { Variety (HYV) RH } \\
\text { 0749, Seed treatment } \\
\text { with bavistin \& } \\
\text { biofertilizers, } \\
\text { Orobanche } \\
\text { (Weed)management, } \\
\text { Fertilizers dose as per } \\
\text { recommendation }\end{array}$ & 22.20 & 17.00 & 30.60 \\
\hline 2016-17 & 75 & $\begin{array}{l}\text { High Yielding } \\
\text { Variety (HYV) RH } \\
\text { 0749,Seed treatment } \\
\text { with bavistin \& } \\
\text { biofertilizers, } \\
\text { Orobanche } \\
\text { (Weed)management, } \\
\text { Fertilizers dose as per } \\
\text { recommendation }\end{array}$ & 23.00 & 15.60 & 47.40 \\
\hline 2017-18 & 100 & $\begin{array}{l}\text { High Yielding } \\
\text { Variety (HYV) RH } \\
0749, \text { Seed treatment } \\
\text { with bavistin \& } \\
\text { biofertilizers, } \\
\text { Orobanche (Weed) } \\
\text { management, } \\
\text { Fertilizers dose as per } \\
\text { recommendation }\end{array}$ & 21.90 & 14.90 & 46.90 \\
\hline
\end{tabular}

Table.4 Economic analysis of front line demonstrations of mustard on farmers' field

\begin{tabular}{|l|c|c|c|c|c|c|c|c|}
\hline Year & \multicolumn{3}{|c}{$\begin{array}{c}\text { Economics of demonstration } \\
\text { (Rs./ha) }\end{array}$} & \multicolumn{3}{c|}{ Economics of check(Rs./ha) } \\
& Gross & Gross & $\begin{array}{c}\text { Net } \\
\text { Return }\end{array}$ & BCR & $\begin{array}{c}\text { Gross } \\
\text { Cost }\end{array}$ & $\begin{array}{c}\text { Gross } \\
\text { Return }\end{array}$ & $\begin{array}{c}\text { Net } \\
\text { Return }\end{array}$ & BCR \\
\hline & Cost & Return & & BCR & & & & \\
\hline $\mathbf{2 0 1 5}-16$ & 44390 & 73520 & 29130 & 1.66 & 4345 & 62380 & 18925 & 1.44 \\
\hline $\mathbf{2 0 1 6 - 1 7}$ & 34560 & 59145 & 24585 & 1.71 & 33750 & 51507 & 17757 & 1.14 \\
\hline $\mathbf{2 0 1 7 - 1 8}$ & 46273 & 71254 & 24981 & 1.54 & 45251 & 63245 & 17994 & 1.40 \\
\hline
\end{tabular}


Table.5 Gap analysis of front line demonstrations of mustard on farmers' field

\begin{tabular}{|c|c|c|c|c|c|c|c|}
\hline Year & $\begin{array}{l}\text { Technology } \\
\text { demonstrated }\end{array}$ & $\begin{array}{c}\text { Potential } \\
\text { yield } \\
(\mathbf{q} / \mathbf{h a})\end{array}$ & $\begin{array}{c}\text { Demonstrat } \\
\text { ion yield } \\
\text { (q/ha) }\end{array}$ & $\begin{array}{c}\text { Farmers' } \\
\text { Practice yield } \\
\text { (q/ha) }\end{array}$ & $\begin{array}{l}\text { Extension } \\
\text { gap }\end{array}$ & $\begin{array}{c}\text { Technolo } \\
\text { gy gap }\end{array}$ & $\begin{array}{l}\text { Technology } \\
\text { Index }\end{array}$ \\
\hline 2015-16 & $\begin{array}{l}\text { High Yielding Variety } \\
\text { (HYV) RH 0749,Seed } \\
\text { treatment with bavistin } \\
\& \text { biofertilizers, } \\
\text { Orobanche (Weed) } \\
\text { management, Fertilizers } \\
\text { dose as per } \\
\text { recommendation }\end{array}$ & 32 & 22.20 & 17.00 & 5.20 & 9.8 & 30.62 \\
\hline 2016-17 & $\begin{array}{l}\text { High Yielding Variety } \\
(\text { HYV) RH 0749,Seed } \\
\text { treatment with bavistin } \\
\& \text { biofertilizers, } \\
\text { Orobanche (Weed) } \\
\text { management, Fertilizers } \\
\text { dose as per } \\
\text { recommendation }\end{array}$ & 32 & 23.00 & 15.60 & 7.40 & 9.0 & 28.12 \\
\hline 2017-18 & $\begin{array}{l}\text { High Yielding Variety } \\
(\text { HYV) RH 0749,Seed } \\
\text { treatment with bavistin } \\
\& \text { biofertilizers, } \\
\text { Orobanche (Weed) } \\
\text { management, Fertilizers } \\
\text { dose as per } \\
\text { recommendation }\end{array}$ & 32 & 21.90 & 14.90 & 7.00 & 10.1 & 31.56 \\
\hline
\end{tabular}

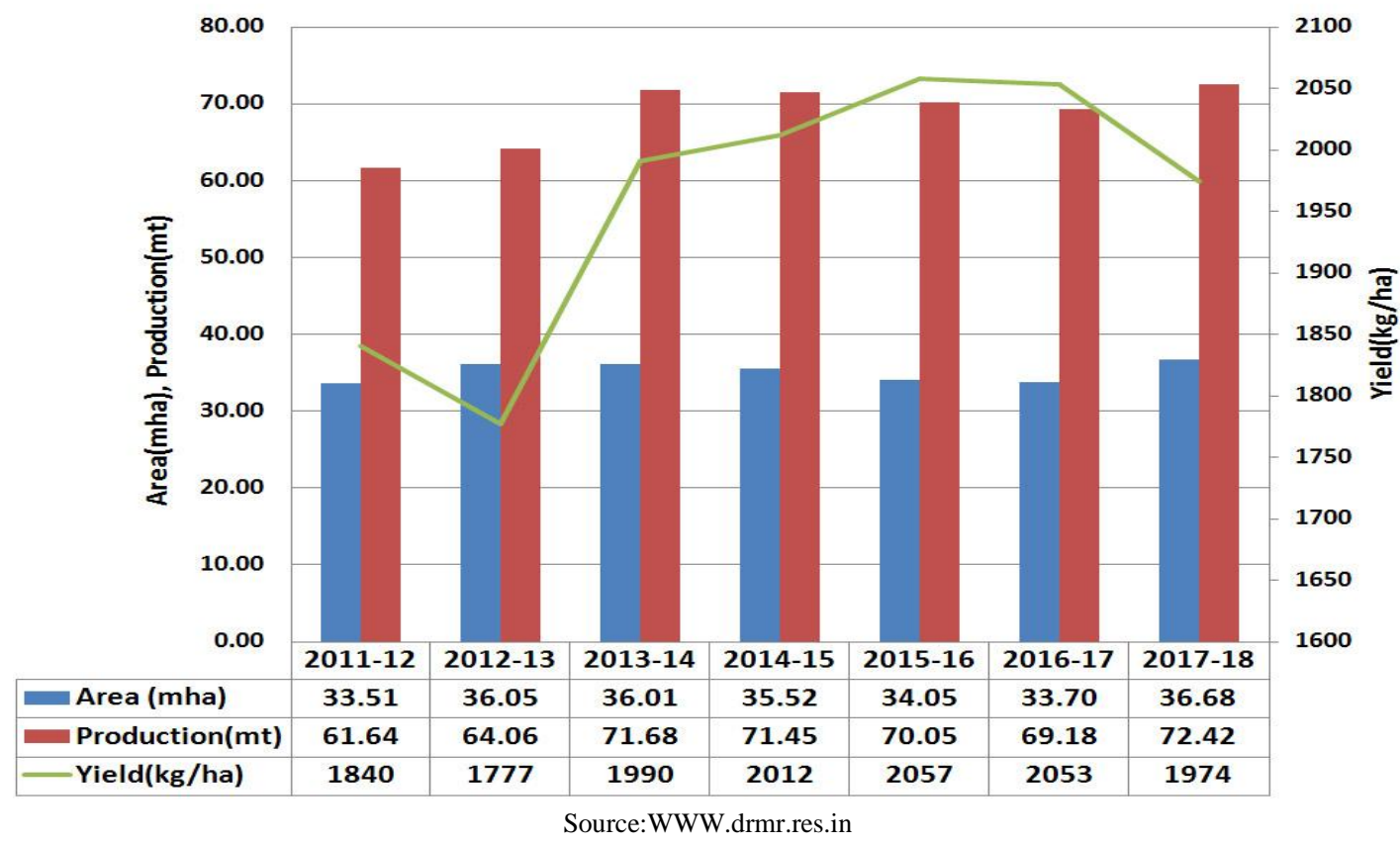

Graph.1 Rapeseed-Mustard Production trends in World 


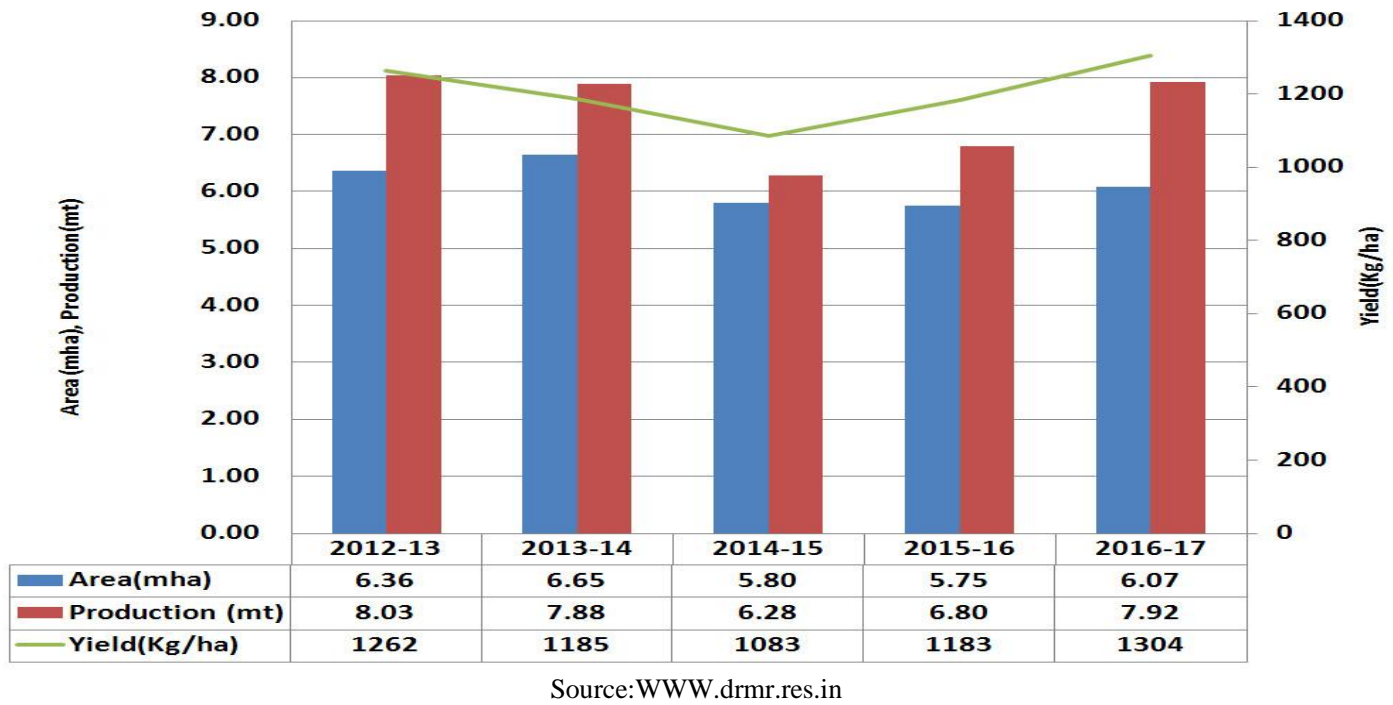

Graph.2 Rapeseed-Mustard Production trends in India

The study emphasizes the needs to educate the farmers in adoption of improved technology to narrow the extension gaps through various technology transfer centers. Therefore it is suggested that these factors may be taken for considered to increase the scientific temperament of the farmers.

\section{References}

Balai, C.M., Meena, R.P., Meena, B.L. and Bairwa, R.K.2012. Impact of frontline on rapeseed and mustard yield improvement. Indian Res. J. of Ext.n Edu., 12 (2): 113116.

Chaudhary, R. P., Choudhary, Govind Kumar, Prasad, R., Singh, Rekha and Chaturvedi, A. K.2018 Impact Assessment of Front Line Demonstration on Mustard Crop. Int. J. Curr. Microbiol. App. Sci. Special Issue7: 4737-4742.

Dhaka, B. L., Meena, B. S. and Suwalka, R. L.2010. "Popularization of Improved Maize production technology through frontline demonstrations in south-eastern Rajasthan".Journal of Agri. Sci., 1(1):3942.

Hiremath, S. M., Nagaraju, M. V. and Shashidhar, K. K.2007. "Impact of frontline demonstration on onion productivity in farmers field". Nation. Sem. Appropriate
Extn.Strat. Manag.Rural Resources, Univ. agric. Sci. Dharward. December 18-20:100.

Mitra, B. and Samajdar, T.2010. Yield gap analysis of rapseed and mustard through frontline demonstrations. Agril. Ext. Review, 22 (2):16-17.

Patel, M. M., Jhajharia, A. K., Khadda, B. S. and Patil, L. M. 2013. "Frontline demonstration: An effective communication approach for dissemination of sustainable cotton production technology". Ind. J. Extn.Edu. \& R.D., 21: 60-62.

Samui, S K, Maitra, S, Roy, DK, Mandal, A K and Saha, D. 2000.Evaluation of front line demonstration on groundnut. J Indian Soc Coastal Agric Res, 18: 180-183.

Singh, R.K., and Kumar, H. 2012. On Farm Evaluation of Front Line Demonstrations on Mustard in Estern Plane Zone of Uttar Pradesh. Indian Journal of Extension Education, Vl. 48, No. 3 \& 4, 2012 (115117).

Tiwari, K.B. and Saxena, A.2001. Economic analysis of FLD of oilseed in Chhindwara. Bhartya Krishi Anusandhan Patrika, 16 (3\&4): 185-189.

Tiwari, K.B., Singh, Vinay and Parihar, P.2003. Role of FLD in transfer of gram production technology. Maharastra J.Extn.Edu., 22 (1):19. 


\section{How to cite this article:}

Vinod Kumar and Jakhar. D. S. 2020. Impact Assessment of Front Line Demonstrations on Musard (Brassica juncea) in Bhiwani District of Haryana. Int.J.Curr.Microbiol.App.Sci. 9(04): 395-402. doi: https://doi.org/10.20546/ijcmas.2020.904.047 